УДК. 619:614.31.636.087.636/58 DOI 10.31210/visnyk2018.03.27

(C) 2018

Данкевич Н. І., здобувач

(науковий керівник - доктор ветеринарних наук, професор, заслужений діяч науки і техніки України В. М. Ковбасенко)

Одеський державний аграрний університет

\title{
ВПЛИВ КОРМОВИХ ДОБАВОК ІЗ МОРСЬКИХ ГІДРОБІОНТІВ НА ПРОДУКТИВНІСТЬ КАЧЕНЯТ-БРОЙЛЕРІВ
}

\section{Рецензент - доктор ветеринарних наук, професор, заслужений діяч науки і техніки Украӥни В. М. Ковбасенко}

Представлено результати досліджень кормових добавок із морських гідробіонтів, білково-мінеральної та мінеральної, виготовлених за розробленими нами технологіями, які підтверджені патентами Украӥни на корисну модель: № 42687 «Спосіб одержання кормової добавки з морських гідробіонтів для птииіi» від 10.07.2009; № 34634 «Спосіб одержання кормової добавки з морських гідробіонтів для птииі» від 11.08.2008. Їх використанні в кількості $10 \%$ у раціоні каченят-бройлерів позитивно впливає на продуктивність каченят, не знижує приріст живої маси, сприяє збереженню каченят при вирощуванні та незначним середньодобовим приростам живої маси.

Ключеві слова: морські гідробіонти, жива маса, приріст, каченята-бройлери, мінеральна добавка, білково-мінеральна добавка, морська вода, «йодка».

Постановка проблеми. В останні роки в країні знизилось виробництво продукції тваринництва, що пояснюється не тільки зменшенням поголів'я тварин та птиці, а і скороченням виробництва кормів, значно скоротилась питома вага білково-мінеральних кормів тваринного походження. У зв'язку з цим особливого значення набуває проблема пошуку кормових джерел нетрадиційної сировини. Одним із таких джерел можуть бути морські гідробіонти (мідії, водорості, морська вода), які мають повноцінні білки, мінерали та їх біологічно цінні речовини, необхідні для росту і розвитку організму тварин i птиці. Особливе значення має використання кормів із морських гідробіонтів у м'ясному птахівництві - одному з найбільш швидких галузей тваринництва $[3,4,7]$.

Аналіз останніх досліджень і публікацій, у яких започатковано розв'язання проблеми. Були проведені комплексні багаторічні дослідження колективом кафедри ветеринарносанітарної експертизи з використанням морських гідробіонтів у якості сировини для виготовлення нетрадиційних кормів. Так, було виготовлено корисну модель, яка має безпосереднє відно- шення до сільського господарства, зокрема птахівництва, при вирощуванні та утриманні птиці: спосіб отримання кормової добавки із мідій (авторське свідоцтво СРСР №1479050 А1, А23 К1/10 від 23.03.91, бюл. №3). Недоліком цього способу $є$ те, що добавка містить стулки мідій, механічно подрібнених до стану крупи, тобто мінеральні речовини у формі, що погано засвоюється організмом птиці. Найбільш близьким аналогом є спосіб отримання коралової добавки із мідій (авторське свідоцтво СРСР №935062 МПК А23К1/10 від 15.06.82, бюл. №22) [1], де в якості кормових компонентів використовували цілі мідії. Недоліком найближчого аналогу є недостатній вміст мінеральних компонентів, оскільки м'ясо мідій - це білковий компонент.

У зв'язку з цим, метою роботи було удосконалити спосіб отримання кормових добавок із морських гідробіонтів та вивчити їх вплив на продуктивність каченят-бройлерів.

Матеріал та методика досліджень. Об'єктами досліджень у використаній роботі були: каченята-бройлери на відгодівлі; кормові добавки 3 морських гідробіонтів: білково-мінеральна та мінеральна, виготовленні за розробленою нами технологією шляхом подрібнення відходів від первинної переробки мідій і відходів агарового виробництва - "йодка", та часткового їх гідролізу до отримання пастоподібної маси $[5,6]$.

Для вивчення впливу кормових добавок нами відібрано, за принципом аналогів, 240 каченят десятиденного віку, з яких було сформовано 6 груп: 2 контрольні, 4 піддослідні, по 40 каченят кожна.

Вся птиця протягом досліду знаходилась в однакових умовах і отримувала основний кормовий раціон, що використовувався в господарстві і був збалансований за основними питомими речовинами, відповідно до діючих норм [2]. Вивчення впливу кормових добавок на продуктивність каченят-бройлерів проводили відповідно до діючих інструкцій та нормативних документів [8]. 
Результати досліджень. Відповідно до методики досліджень, каченята контрольних і підконтрольних груп протягом 8 діб (з 12- до 20денного віку) знаходились на однаковому основному кормовому раціоні (ОР), лише 3 21-го дня до кінця дослідження (тобто, період відгодівлі 60 діб) каченятам в основний кормовий раціон додавали пастоподібні кормові добавки в кількості $10 \%$ маси раціону. Кормові добавки ми використовували у двох напрямах: заміна 10 \% основного кормового раціону і збагачення його додаванням до раціону $10 \%$ кормових добавок за схемою (табл. 1).

Проведеними дослідженнями встановлено, що використання білково-мінеральної добавки 3 морських гідробіонтів позитивно впливає на ріст каченят-бройлерів, незалежно від способу застосування. 3 результатів досліджень, наведених у таблиці №2, видно, що заміна в основному кормовому раціоні $10 \%$ корму білково-мінеральною добавкою не знижує приріст живої маси, він у каченят піддослідної групи був на рівні контрольного $(100,4 \%)$. Збагачення кормового раціону каченят $10 \%$ білково-мінеральною добавкою сприяє підвищенню інтенсивності приросту живої маси на 6,9\%, підвищенню відносної швидкості росту і збільшує збереженість каченят на 5,6\%.

Використання мінеральної добавки при вирощуванні каченят за запропонованою нами схемою менш впливає на продуктивність каченят, але все таки сприяє росту та розвитку. 3 результатів досліджень, наведених у таблиці №3, видно, що заміна в кормовому раціоні $10 \%$ корму мінеральною добавкою практично не впливає на ріст i розвиток каченят. Отримані показники приросту живої маси, відносної швидкості росту не відрізняються від каченят контрольної групи.

Але збагачення раціону $10 \%$ мінеральної добавки сприяє збільшенню приросту живої маси каченят на 4,9 \% в порівнянні $з$ каченятами контрольної групи. Підвищується інтенсивність росту і збереження каченят на 3,9 \%.

Узагальнюючи результати проведених досліджень, можна відмітити, що 3 метою інтенсивності та стійкості вирощування каченятбройлерів доцільно використовувати у кормових раціонах кормові добавки з морських гідробіонтів, виготовлених за розробленою нами технологією.

\section{1. Схема проведення досліду}

\begin{tabular}{|c|c|c|c|}
\hline \multirow{2}{*}{ Кормові добавки } & \multirow{2}{*}{ Групи } & \multicolumn{2}{|c|}{ Періоди досліду (діб) і раціон } \\
\hline & & Порівняльний (12-20) & Основний (21-60) \\
\hline $\begin{array}{l}\text { Білково-мінеральна } \\
\text { добавка }\end{array}$ & $\begin{array}{l}1 \\
2 \\
3\end{array}$ & $\begin{array}{c}\text { ОР - контрольна } \\
\text { ОР } \\
\text { ОР }\end{array}$ & $\begin{array}{c}\text { ОР - контрольна } \\
90 \% \text { ОР + } 10 \% \text { БМД } \\
100 \% \text { ОР }+10 \% \text { БМД }\end{array}$ \\
\hline Мінеральна добавка & $\begin{array}{l}1 \\
2 \\
3\end{array}$ & $\begin{array}{c}\text { ОР - контрольна } \\
\text { ОР } \\
\text { ОР }\end{array}$ & $\begin{array}{c}\text { ОР - контрольна } \\
90 \% \text { ОР + } 10 \% \text { МД } \\
100 \% \text { ОР + } 10 \% \text { МД }\end{array}$ \\
\hline
\end{tabular}

Примітка: ОР - основний раціон; БМД - білково-мінеральна добавка; МД - мінеральна добавка.

2. Вилив білково-мінеральної добавки з морських гідробіонтів на продуктивність каченят, $M \pm m, n-40$

\begin{tabular}{|c|c|c|c|c|}
\hline \multirow{2}{*}{$\begin{array}{c}\text { № } \\
\text { п/п }\end{array}$} & Показники & \multicolumn{3}{|c|}{ Групи } \\
\cline { 3 - 5 } & & 1 & 2 & 3 \\
\hline 1 & Жива маса на початку & $510 \pm 1,6$ & $508 \pm 2,4$ & $504 \pm 1,2$ \\
& основного періоду, Г & & & \\
\hline 2 & Жива маса в кінці досліду, & $2290 \pm 2,34$ & $2300 \pm 3,26$ & $2450 \pm 2,32$ \\
& \% до контролю & 100,0 & 100,4 & 100,9 \\
\hline 3 & Загальний приріст живої маси, г & $1780 \pm 3,62$ & $1792 \pm 4,12$ & $1946 \pm 4,21$ \\
\hline 4 & Середньодобовий приріст живої & $44,5 \pm 1,66$ & $44,8 \pm 1,32$ & $48,6 \pm 2,21$ \\
& маси, г & 128,2 & 129,0 & 134,4 \\
\hline 5 & Відносна швидкість росту & 92,6 & 95,4 & 98,2 \\
\hline 6 & Збереження & & & \\
\hline
\end{tabular}


3. Вилив мінеральної добавки з морських гідробіонтів на продуктивність каченят, $M \pm m, n-40$

\begin{tabular}{|c|c|c|c|c|}
\hline \multirow{2}{*}{$\begin{array}{c}\text { № } \\
\text { п/п }\end{array}$} & Показники & \multicolumn{3}{|c|}{ Групи } \\
\cline { 3 - 4 } & & 1 & 2 & 3 \\
\hline 1 & $\begin{array}{c}\text { Жива маса на початку основного } \\
\text { періоду, Г }\end{array}$ & $502 \pm 1,21$ & $504 \pm 3,26$ & $505 \pm 1,36$ \\
\hline 2 & Жива маса в кінці досліду, \\
\% до контролю & $2292 \pm 2,12$ & $2286 \pm 3,24$ & $2406 \pm 2,24$ \\
& 100,0 & 99,7 & 104,9 \\
\hline 3 & Загальний приріст живої маси, г & $1790 \pm 3,69$ & $1782 \pm 1,12$ & $1821 \pm 2,32$ \\
\hline 4 & Середньодобовий приріст живої & $44,7 \pm 0,6$ & $44,5 \pm 0,3$ & 45,5 \\
\hline 5 & маси, г & & & 126,4 \\
\hline 6 & Відносна швидкість росту & 127,0 & 93,6 & 97,3 \\
\hline
\end{tabular}

\section{Висновки:}

1. Кормові добавки з морських гідро біонтів, виготовленні за розробленою нами технологією, можна використовувати при вирощуванні каченят-бройлерів як нетрадиційну сировину для збагачення кормового раціону білками та мінеральними речовинами.

2. Збагачення кормових раціонів каченят білково-мінеральною добавкою в кількості $10 \%$ до

\section{БІБЛІОГРАФІЯ}

1. А. с. 935062 СССР, МКИ А 23 К1/10. Способ производства кормовой добавки из мидий / В. М. Ковбасенко, Ю. Б. Крук, А. Е. Гайдай, В. А. Семенец. - № 3220883/ 30 - 15; заявл. 13.11.80; опубл. 15.06.82, бюл. № 22.

2. Вайдянин Г. В. Промышленное производство мяса бройлеров - на научную основу / Г. А. Вайдянин, Г. Н. Вайдянин, В. П. Белошестов // Хранение и переработка сельхозсырья. 2003, №10. - C. 23-30.

3. Демчук М. В. Гігієна тварин: підручник видання - др. видання / М. В. Демчук, В. М. Чорний, М. О. Захаренко, М. П. Високос. - Харків : Ескада, 2006. - С. 520.

4. Ковбасенко В. М. Методичні рекомендації по переробці відходів мідій у кормове борошно, використання його в птахівництві: Методичні маси раціону або заміна такою кількістю добавки кормового раціону сприяє збільшенню приросту живої маси каченят на $6,9 \%$, збільшенню швидкості росту та збереженості каченят.

3. Збагачення кормових раціонів мінеральною добавкою сприяє приросту живої маси каченят на 4,9\%. Заміна корму в раціоні каченят мінеральною добавкою в кількості $10 \%$ не впливає на їх продуктивність.

рекомендації / В. М. Ковбасенко, Ю. А. Гарнаженко. - ОГАУ. - Одеса, 2006. - 22 с.

5. Люмінісцентний матеріал: пат. 34634 Украіна: МПК51 А23К 1/175. № 200808275; заявл. 19.06.08; опубл. 11.08.08, бюл. №15. -4 c.

6. Люмінісцентний матеріал: пат. 42687 Україна: МПК51 А23К 1/10, А23К 1/175. № 200903402; заявл. 09.04.09; опубл. 10.07.09, бюл. №13. -4 c.

7. Свеженцов А. И. Нетрадиционныекормовые добавки для животних и птицы. / А. И. Свеженцов, В. Н. Коробко. - Днепропетровск, 2004. C. 296.

8. Симоркін Л. Птахівництво в Україні / Л. Симорокін // Сучасне птахівництво - 2014. №3. - C. 3-10.

\section{ANNOTATION}

Dankevych N. I. The impact of sea hydrobiont additives on broiler ducklings.

Recently the production of livestock production has decreased in the country. It accounts for the reduction of animal and bird livestock, fodder production, the proportion of protein-mineral food of animal origin. In this regard the problem of surching alternative animal feed resources is becoming particularly important. Sea hydrobionts possessing sustainable proteins and valuable biodiversity crucial for growth and development of animals and birds are suggested to be one of such precious sources. Using sea hydrobiont forage in poultry farming is of crucial importance as it is one of the fastest-growing branches of animal industry.

The purpose of the research in view of the above, 
the tusk is to consider the impact sea hydrobiont additives on broiler ducks productivity.

The study focuses on sea hydrobiont additives both protein-mineral and mineral produced according to our own designed technology by means of shredding mussels primary processing and agrarian wastes (iodine).

The study of sea hydrobionts impact on broiler ducks productivity was carried out under existing instructions and regulatory documents.

In accordance with the study methodology control and test groups of ducks were provided with staple ration for 8 days (aged from 12 to 20 days). From the $21^{\text {st }}$ day till the end of the period (60 days in total) their ration was enreached by paste-like additives in the amount of $10 \%$ to the staple ration. We used the additives in 2 ways: $10 \%$ replacement of the staple ration with additives and adding extra $10 \%$ of additives to enreach the staple ration.

In the course of the study it was found that using protein-mineral hydrobiont additives has a positive effect on broiler ducks growth regardless the way used. The $10 \%$ replacement of the staple ration with hydrobiont additive does not reduce body weight gain which made up $100.4 \%$ in the test group of ducks. Adding extra $10 \%$ of protein-mineral additive to the ration increases the intensity of body weight gain by $6.9 \%$, relative growth rate and survival rate of ducks by $5.6 \%$.

The impact of mineral additive on ducks productivity when raised them according to our scheme is less but at the same time it contributes to ducks growth and development. The $10 \%$ replacement of the ration with mineral additive does not have a big impact on growth and development.

But adding extra $10 \%$ of mineral to the ration increases the intensity of live body weight gain by $4.9 \%$ compared to the control group of ducks. The growth rate and conservation rate are also increased by $3.9 \%$.

Sea hydrobiont additives produced according to our own technology can be used when raising broiler ducks as non-traditional source of proteins and minerals for staple ration. Enreaching the ration of ducks by protein-mineral additive in the amount of $10 \%$ or replacing the ration by the same amount of the additive allows to increase their body weight gain by $6.9 \%$ as well as relative growth and conservation rate. Enreaching the ration by mineral additive increases body weight gain of ducks by $4.9 \%$. The $10 \%$ replacement with such an additive does not effect their productivity.

Key words: sea hydrobionts, body weight gain, broiler ducklings, mineral additive, protein-mineral additive, sea water, «Iodine». 